\title{
THE REPRESENTATION AND OVERCOMING OF PERPETRATOR TRAUMA IN RACHEL SEIFFERT'S AFTERWARDS
}

Keywords: acting out; combat veteran; holes; palimpsestic structure; perpetrator trauma; Rachel Seiffert; working through

Abstract: Rachel Seiffert's novel Afterwards (2007) explores the ethically challenging and often neglected fact of perpetrator trauma resulting from sustained structural violence. This controversial subject is conveyed through the stories of Joseph and David, two British ex-servicemen belonging to different generations, who attempt to overcome their war traumas years after their respective involvement in The Troubles in Northern Ireland (from the late 1960s to the Good Friday Agreement of 1998), and the Mau Mau Uprising (running from 1952 to 1960), that ended with Kenya's independence. The novel fittingly organises the narrative around moments of acting-out, when the protagonists feel equally disconnected from self and world, yet deal with their traumatised condition in strikingly different ways. The paper proposes an analysis of Afterwards from the perspective of Trauma and Memory Studies, with a view to exploring how the "palimpsestuous" (Dillon 4) structure of the novel, along with the repetitive use of imagery evoking holes and emptiness (Bloom 210), allow Seiffert to "perform" (Ganteau and Onega 10) the workings of the disturbed psyches of Joseph and David, so that it builds the unrepresentability of trauma into the textual fabric of the novel.

Ever since its inclusion in official psychiatric diagnostics in 1980, PostTraumatic Stress Disorder (PTSD) has been traditionally attributed to victims of traumatic experiences or those who helped them. However, at the turn of the century, scholars like Dominick LaCapra (2014) have recognised that perpetrators can also be shocked and disturbed after using violence against others. In 2005, psychologist Rachel MacNair developed a subsection of PTSD devoted to perpetrator trauma that she called "Perpetration-Induced Traumatic Stress" (PITS). Her main contention was that victimisers can not only experience intrusive symptoms such as flashbacks, nightmares and unwanted thoughts but that these symptoms can be greater than those suffered by innocent victims because of the factor of agency in perpetration (97). This turn to perpetrator trauma is controversial because of the ethical implications entailed in the study of persons who hurt others. ${ }^{1}$

A central tenet of academic perpetrator trauma is that focussing on the aggressors enables critics to demystify their traditional portrayal as monsters and posit

\footnotetext{
${ }^{*}$ Universidad de Zaragoza; Spain.

${ }^{1}$ As Jenni Adams (2013) points out, the controversy over the turn to perpetrator trauma is centred on the risks of downplaying victim experiences and giving an uncritical consideration to victimisers that might exonerate them from their crimes or enable unacceptable reader identification with them (2).
} 
Trauma, Narrative, Responsibility

them as human beings who make ethically wrong choices within a specific sociopolitical framework and can therefore be traumatised (Mohamed 1208; Pettitt 4). When an individual decides to crush what Lieutenant Colonel Dave Grossman (1996) calls the "powerful, innate human resistance toward killing one's own species" (xxix), consequences can be devastating.

The possibility of gathering a better understanding of history and humanity is probably the main reason why many contemporary authors have started writing on the wrongdoer rather than on the victim in their representation of traumas. According to Roger Luckhurst, the intractability of the Holocaust provides "a comparative measure and metaphor for all atrocity" (69) - an aspect which explains why perpetrator fiction usually deals with Nazis during or in the aftermath of the Second World War. A central representative of this trend is Rachel Seiffert, a British author with Nazi ancestry on her mother's side. Having tackled the Holocaust legacy from the Nazi perspective in her first novel, The Dark Room (2001), ${ }^{2}$ she resumes perpetrator trauma, guilt and responsibility in the second, Afterwards (2007), from the perspective of British combat veterans.

Afterwards narrates the stories of Joseph and David, two ex-servicemen who attempt to come to terms with their traumas years after their respective involvement in The Troubles in Northern Ireland and the suffocation of the Mau Mau uprising in Kenya. The active participation of Seiffert's protagonists in different acts of manslaughter transforms them into victims of perpetrator trauma or PITS. Echoing Anne Whitehead's outlook on the trauma novel (2004), Afterwards does not focus on "the question of what is remembered of the past" but in "how and why it is remembered” (3). Thus, although Joseph's and David's stories are located within specific historical frameworks, Seiffert highlights the moments when her characters are particularly vulnerable, when they feel dislocated from the world and from themselves. Drawing on this, I will briefly analyse the ways in which the experimental structure of the novel, along with the repetitive use of imagery evoking holes and emptiness, allow Seiffert to represent the workings of Joseph's and David's disturbed psyches.

In her seminal work Unclaimed Experience: Trauma, Narrative, and History (1996), Cathy Caruth, drawing on Freud, defines trauma as "a wound inflicted . . . upon the mind" caused by an event which is so overwhelming that it cannot be fully experienced (3). The individual can only cope with it through the repression of affects and psychic dissociation. Also echoing Freud, psychoanalysts like Sandra L. Bloom or Gabriele Schwab (2010) agree that dissociation can help the subject deny lifethreatening aspects of reality at a given moment. However, when the traumatic experiences are not integrated into the psyche in the long run, they can come back belatedly, after what Freud called the "period of latency" (Moses 117), giving way to the phase of "repetition compulsion" or "acting out" (LaCapra xxiii) of the traumatic event in the form of intruding thoughts, nightmares or hallucinations. As a result, trauma is located in how its unassimilated nature haunts the survivor after the original

\footnotetext{
${ }^{2}$ In the novella triptych The Dark Room (2001), Seiffert explores the Holocaust legacy just before and during the Second World War, immediately after, and in its aftermath, through the stories of three ordinary Germans.
} 
Trauma, Narrative, Responsibility

event (Caruth, Unclaimed 4). Nonetheless, individuals can overcome the phase of repetition compulsion and work towards recovery or "working through" of their trauma by abreacting it, either in deeds or words, and situating it in the past so as to move forward in their lives. In LaCapra's words:

Working through trauma involves the effort to articulate or rearticulate affect and representation in a manner that may never transcend, but may to some viable extent counteract, a reenactment, or acting out, of that disabling dissociation. (La Capra 42)

Inscribed on the psyche as a non-experience, the memory of the shocking situation defies meaning and interpretation, posing epistemological problems when the survivor attempts to verbalise it. The traumatised subject's inability to unearth and cast a logical narrative pattern on the incomprehensible painful events is reflected in Seiffert's experimental text. The author structures Afterwards around a narrative void, what Bloom appositely describes as "the black hole of trauma" (210) left in the psyche by the "collapse of . . . understanding" (Caruth Explorations 7). In this sense, it may be stated that the novel contests the unrepresentability of trauma by building it into its own textual fabric, as Jean-Michel Ganteau and Susana Onega contend, "performing the void instead of anatomising it” (10). The events taking place in the narrative loop around, but never address directly the protagonists' traumatising acts of manslaughter during their military service, thus integrating their perpetrator traumas into the narration of their present lives. This echoes Jean-François Lyotard's observation that, when art is confronted with trauma, the only thing it can do is to record its unrepresentability, so that if it "does not say the unsayable", at least it "says that [it] cannot say it” (qtd in Pellicer-Ortín 42).

Although the narrative form adapts to this fissure, it also reveals the traces of the two characters' repressed traumatic secrets, only perceptible in the form of gaps and silences, anachronisms and flashbacks, formal fragmentation and the slowing down of narrative rhythm. Thus, an underlying text from the past emerges into the present, like the traces of the older text tainting the overlying one as in a palimpsest. In this sense, it can be said that the narrative structure of the novel begs for what Sarah Dillon, drawing on Gérard Genette (1982), calls a "palimpsestuous" or "relational" reading (63-84) demanding the active involvement of the reader. Dillon highlights the similarities between textual palimpsests and Nicolas Abraham and Maria Torok's post-Freudian exploration of the mind as a mystic writing pad (41). ${ }^{3}$ Both psyche and literary texts are layered, with the unintegrated fragments haunting consciousness and the text. Like a therapist of sorts, the reader of Afterwards must confront an elusive narrative that requires a "reading through [of its] layers of significance" and attention "to the play of meaning between [the] given text and its intertexts" (Collecott 1999, qtd in Dillon 107; original emphasis). Since Afterwards is about the imprint left by trauma on Joseph's and David's affects and speech, the reader can only grasp the truth performed by the narrative by becoming what Roland Barthes called a "scriptor"

\footnotetext{
${ }^{3}$ According to Abraham and Torok (1994), the individual buries the unspeakable traumatic scene within his or her self in a psychic "crypt", thus precluding its assimilation and turning it into a lurking memory. The repressed memory acts then retroactively in the form of mnemonic traces that haunt the individual's consciousness.
} 
(Barthes, "The Death of the Author" 145), that is, an active producer of meaning that "holds together in a single field all the traces by which the written text is constituted" ("The Death of the Author" 148).

Besides the palimpsestic structure of the novel, Seiffert also employs images evoking holes and empty spaces to add consistency and intensity to the narrative. Although David belongs to Joseph's father's generation, similarities can be drawn between the two protagonists from the very beginning of the novel. One is the fact that they are the only characters given a voice in the first chapter; another, that both have meted out death in the line of duty. Imagery related to hole drilling is already explicit in their traumatic primal scenes. In Joseph's case, the shooting of an IRA member at a checkpoint in Armagh in order to save the life of a comrade, left everything "shot through with holes" (A 257). In David's case, the dropping of bombs on the Aberdare Mountains from his combat aircraft is described as a perforation of the Kenyan landscape (A 7). These holes represent not only their violent acts but also the psychic consequences on both characters afterwards. As Eve, Joseph's sister, reflects at one point: "What kind of person comes away from that with peace of mind?” (A 302). The connection between both men is further strengthened when, in their introduction to each other by Alice, Joseph's girlfriend and David's granddaughter, David "look[s] happy to have someone who kn[ows] what he [i]s talking about" (A 96-97). They get on well, as they recognise in the other a fellow veteran who may understand their identity crisis and marginal position in society in the aftermath of their respective armed conflicts.

However, according to Andrew Monnickendam, the resemblance between Joseph and David is only an "apparent parallel" (185). The conditions in which each perpetrates military violence are markedly different and this is reflected in the impact perpetrator trauma has on their lives and the coping strategies they adopt to overcome it. Joseph joined the army as a teenager as a way to escape the futility of his school years. The impulsiveness of his decision shows him psychologically unprepared to become a soldier and explains why he ended up hating the military, where he felt like a "uniform walking empty" (A 191), as well as the dramatic impact that firing a bullet had on him. In the narrative present, Joseph is often possessed by nightmares about the shooting and assailed by intense sensory reminiscences while he is awake. Intrusive thoughts often take him back to the moments before or after the traumatic event. Affective paralysis is evident in his failure to have fulfilling love relationships, as now happens with Alice and had happened before with Julie. Whenever he is pushed by his girlfriends to talk about his past, Joseph represses his memory and remains "wordless", leaving his "gap[s] . . wide open" (A 211). Once, three years after he returned from Northern Ireland, Joseph visited Jarvis, his old Corporal, who helped him remember what happened in the shooting and why he pulled the trigger. After the talk, Joseph was impatiently "waiting for that click, the relief when something starts to make sense" ( $A$ 267), but that click did not occur because feelings of guilt and shame always prevented him from sharing his story. In fact, the closest he ever is to verbalising his perpetrator trauma is when he tells an invented story to his ex-girlfriend Julie in which he is a mere witness of the perpetration (A 290-91). This reticence explains why we learn about his act of perpetration through the traces that haunt his thought process, as is illustrated when he reflects: 
You think about it and think about it, you do nothing else. Only remember, and then you let yourself stop. . . . If it's not going to help. If you're never going to change it. Why touch the sore part any more than you have to? (A 293)

Conversely, David, as “a son in the empire Training Scheme” (A 133), was eager to become a soldier since he was a child. ${ }^{4} \mathrm{~A}$ cold man now, he is described by his daughter and granddaughter as "blinkered" (A 279), an old-fashioned and limited man with no feelings of remorse for his acts during the suppression of the Mau Mau uprising. However, Joseph, in his commonality with him, knows that David does have a troubled conscience ( $A$ 292). Indeed, the old man seems to be living elsewhere in the past most of the time. In the garden, which reminds him of the garden he had in Nairobi (A 118), he is often staring vacantly at the horizon, immersed in his own train of thoughts (A 22). In contrast to Joseph, David does talk about his war times in Nairobi. He used to do it with his wife Isobel, when she was alive, and now he tries to do the same with Joseph. David's speech is full of pauses and hesitations, but he turns such incoherencies into a meaningful narrative that enables him to fill the gaps left by trauma. Therefore, although his perspective in the present is lost after the first chapter, it makes sense that it is through his words, reported by Joseph and Alice in the novel, instead of his thoughts, that we learn about his traumatic past:

- You have to understand this was hugely exciting. To be twenty-three and flying across Africa to go swimming ... I had to fly down to Mombasa once, took us past Kilimanjaro on the return leg. One of the most magnificent things I'll ever see. I knew that too, while it was happening. That's just what it felt like. The most enormous privilege.

He was quiet then, but it wasn't like he was waiting. Joseph didn't think he had to do or say anything ... [ [David] paused like that on and off while he was talking, but always picked up again if you let him. (A 245-6)

A significant motif that Seiffert employs for representing David's progress towards the recovery of trauma is the redecoration of his apartment. While Joseph refurbishes David's apartment as a favour to Alice, the old man feels an urgent need to speak of his RAF days in Kenya, admitting his suffering and bewilderment even decades after his tour of duty. Christina Howes (2018) reads the house motif as an analogy of the mind, meaning that "painting, decorating and renovating its rooms figure as psychological restoration, a means to cleanse away the old and begin anew, and to purify and sanitize the mind of traumatic memory" (232). Although therapeutic for David, this unearthing of the traumatic past is devastating for Joseph's psychic stability and causes what Monnickendam, adopting Seiffert's military terms, has referred to as a "sympathetic detonation" (192). Indeed, listening to David, Joseph experiences a re-awakening of his own trauma, which initially makes him verbally uncommunicative and finally surprisingly violent. In one of his last visits to David, Joseph desperately hurls paint across the banisters and walls and throws a pot of paint

\footnotetext{
${ }^{4}$ Indeed, by that time, he used to go to the airfield at Northolt, where he recited the names of the fighter aircrafts he described and studied landing manoeuvres.
} 
through the window. Immediately after this tantalising episode, Joseph is unable to see through the smashed window glass, except through the hole he had made in it ( $A$ 251), symbolising his immersion in the spiral of acting out trauma. David, who must have heard everything, never complains to him or to anyone about the disaster, probably because he has experienced these fits at some other time. At the same time, we learn through Alice that Joseph’s flat looks unfinished.

Joseph didn't have much furniture, said he could never get round to it. His flat was mostly floorboards and crates, with a couple of nice things he'd picked up from skips and on jobs. He'd told Alice it drove his sister mad: he'd been there four years and she said it still looked like he was squatting. (A 196)

This emptiness certainly represents the huge gap left by the trauma of having killed someone and his inarticulateness to describe such an experience. Indeed, Joseph's fondness for "empty places” (A 80) dates back to his return to London from Northern Ireland. From then on, he visited the coast in the South Downs whenever he wanted to spend some time on his own, and this is where he goes after his upsurge of violence in David's apartment.

It seems paradoxical that Joseph, who has shot just one man, is more negatively affected by perpetrator trauma than David, who has bombed thousands. Although the most logical explanation to this is that Joseph needs more time to reach David's mental condition, Rachel MacNair and Dave Grossman concur on stating that trauma is more acute when the act of perpetration is committed face-to-face than impersonally. The fact that David did not see what was happening on the ground as he was dropping bombs, allowed for his "desubjectification" of the victims (Monnickendam 193-94) in a way that allowed him "to know without knowing" (Bloom 202; Herrero and Baelo-Allué 14). As David confides to Joseph, to him, "[the $\mathrm{RAF}$ ] were there to combat the insurgency, but most of the time [he] felt it like being on an exercise" (A 247). By contrast, Joseph bears a greater psychological burden because, as Grossman argues, "[l]ooking to another human being in the eye, making an independent decision to kill him, and watching as he dies due to your action combine to form the single most basic, important, primal, and potentially traumatic occurrence of war" (31). It is probably the immediacy of the shooting as well as the fact that the decision to kill was his and not his superiors' that drills a deeper and blacker hole in Joseph's mind as compared to David's.

As the novel closes, the two characters are in two different stages of their coping with trauma. On the one hand, David, having been sharing his stories for so long, first with Isobel then with Joseph, appears to have reached the stage of working through of his trauma. Recovery is symbolised by his future plans to visit Kenya with his family and the eventual reconstruction and redecoration of his house. On the other, Joseph is unable to integrate the mnemonic and sensory fragments that emerge from his traumatised unconscious. In the last scene of the novel, Alice walks away from him and his empty house:

Joseph stepped out onto the walkway and looked over the side waiting for her to get to the bottom of the stairs. It was a bright day, and the air was warm on his face, but the concrete still felt cold through his socks. The courtyard below him was full of sun, 
Trauma, Narrative, Responsibility

only the stairwell door was in shadow. Alice came out and he thought she might look up. She crossed the courtyard, into the sun, a brief flare of red, and then she was gone. (A 327)

The fact that his doorway is still dark and the concrete floor remains cold points to the little progress Joseph has made with his trauma throughout the novel. However, the possibility that sunlight finally might reach his door and flood his house is also there, as implied by the sunlit yard in front of his very eyes and the warm air caressing his face. Hope for Joseph also resides in the fact that he has painted the walls of his flat and is furnishing his living room, suggesting that, just as he has started caring about his home, he might begin to fill up the holes in his traumatic memory soon, and transform it into a healing narrative memory.

In conclusion, as the analysis has attempted to show, Seiffert's novel Afterwards successfully explores the ethically challenging and often neglected fact of perpetrator trauma resulting from sustained structural violence. She demonstrates that although trauma springs from voluntary action rather than from danger to physical self-integrity, perpetrators also undergo a process of acting out and working through of their traumas of violence. The psycho-emotional mechanisms activated in these stages are echoed formally through the palimpsestic structure and narrative performativity of the novel. This structure begs for a palimpsestuous or relational reading, capable of bringing to the fore the way in which Seiffert tests and contests the limits of narration, in order to weave into the narrative —or in Ganteau and Onega's terms, in order to "present or perform (poiesis) —as opposed to represent (mimesis)" (11; original emphasis) - the silences, discontinuities, uncertainties and frustrations experienced by traumatised individuals. As we have seen, the performativity of the protagonists' traumatic sequelae is further intensified through the recurrent use of images of holes, gaps and emptiness. As a whole, Afterwards may be said to promote a vision of the vulnerability of every human being confronted not only with the anxiety of our own mortality but also, most crucially, with the unethicality of our culture of violence.

\section{Works Cited:}

Abraham, Nicolas, and Maria Torok. The Shell and the Kernel: Renewals of Psychoanalysis, vol. I. Ed. and Trans. Nicholas. T. Rand. Chicago: University of Chicago Press, 1994. Print.

Adams, Jenni. “Introduction.” Representing Perpetrators in Holocaust Literature and Film. Ed. Jenni Adams and Sue Vice. Ilford: Vallentine Mitchell \& Co Ltd, 2013. 1-9. Print.

Barthes, Roland. “The Death of the Author.” 1968. Image - Music - Text. 1977. Trans. Stephen Heath. London: Fontana, 1990. 142-164. Print.

Bloom, Sandra L. "Bridging the Black Hole of Trauma: The Evolutionary Significance of the Arts." Psychotherapy and Politics International 8.3 (2010): 198-212. Print.

Caruth, Cathy. Trauma: Explorations in Memory. Baltimore and London: John Hopkins University Press, 1995. Print. 
—. Unclaimed Experience: Trauma, Narrative, and History. Baltimore and London: Johns Hopkins University Press, 1996. Print.

Collecott, Diana. H.D. and Sapphic Modernism, 1910-1950. Cambridge: Cambridge University Press, 1999. Print.

Dillon, Sarah. The Palimpsest: Literature, Criticism, Theory. London and New York: Bloomsbury Publishing PLC, 2007. Print.

Freud, Sigmund. Moses and Monotheism. Trans. Katherine Jones. Letchworth: Garden City Press, 1939. Print.

_. "Remembering, Repeating and Working-Through (Further Recommendations on the Technique of Psycho-Analysis)." 1914. The Standard Edition of the Complete Psychological Works of Sigmund Freud Vol. XII (1911-1915). Eds and Trans. James Strachey, Anna Freud, Alix Strachey and Alan Tyson. London: Vintage, 2001. 145-56. Print.

Ganteau, Jean-Michel and Susana Onega. "Introduction: Performing the Void: Liminality and the Ethics of Form in Contemporary Trauma Narratives." Contemporary Trauma Narratives: Liminality and the Ethics of Form. Eds. Susana Onega and Jean-Michel Ganteau. London and New York: Routledge, 2014. 1-15. Print.

Genette, Gérard. Palimpsestes: La littérature au second degré. Paris: Éditions du Séuil, 1982. Print.

Grossman, Dave. On Killing: The Psychological Cost of Learning to Kill in War and Society. New York: Little Brown and Company, 1996. Print.

Herrero, Dolores and Sonia Baelo-Allué, eds. Between the Urge to Know and the Need to Deny: Trauma and Ethics in Contemporary British and American Literature, Heidelberg: Universitätsverlag Winter, 2011. Print.

Howes, Christina. Literary Architecture, Dwelling and the Return-Home in the Works of Rachel Seiffert. Diss. Autonomous University of Barcelona, 2018. Accessed on 02/06/2019 at:

https://www.tdx.cat/bitstream/handle/10803/666917/cah1de1.pdf? sequence $=1$ \&isAllowed $=\mathrm{y} /$.

LaCapra, Dominick. Writing History, Writing Trauma. Baltimore: John Hopkins University Press, 2014. Print.

Luckhurst, Roger. The Trauma Question. London: Routledge, 2008. Print.

Lyotard, Jean-François. Heidegger and 'the Jews'. Minneapolis: University of Minnesota Press, 1997. Print.

MacNair, Rachel. Perpetration-Induced Traumatic Stress: The Psychological Consequences of Killing. New York: Praeger, 2005. Print.

Mohamed, Saira. "Of Monsters and Men: Perpetrator Trauma and Mass Atrocity." Columbia Law Review 115 (2015): 1157-1216. Print.

Monnickendam, Andrew. "Getting It All in the Right Order: The Love Plot, Trauma and Ethical Uncertainty in Rachel Seiffert's Afterwards." Alicante Journal of English Studies 29 (2016): 183-97. Print.

Pellicer-Ortín, Silvia. "The Ethical Clock of Trauma in Eva Figes' Winter Journey." Ethics and Trauma in Contemporary British Fiction. Eds. Susana Onega and Jean-Michel Ganteau, Amsterdam and New York: Rodopi, 2011. 37-60. Print. 
Trauma, Narrative, Responsibility

Pettitt, Joanne. Perpetrators in Holocaust Narratives: Encountering the Nazi Beast. Cham, Switzerland: Palgrave MacMillan, 2017. Print.

Schwab, Gabriele. Haunting Legacies: Violent Histories and Transgenerational Trauma. New York: Columbia UP, 2010. Print.

Seiffert, Rachel. The Dark Room. London, UK: Vintage, 2002. Print.

—. Afterwards. London: Vintage, 2008. Print.

Whitehead, Anne. Trauma Fiction. Edinburgh: Edinburgh UP, 2004. Print. 